\title{
PHYSIOLOGICAL POTENTIAL AND CONSERVATION OF MURUCI (Byrsonima crassifolia) SEEDS ${ }^{1}$
}

\author{
CAMILA RIBEIRO DE SOUZA GRZYBOWSKI², \\ WALNICE MARIA OLIVEIRA DO NASCIMENTO ${ }^{3}$, ROSEMEIRE CARVALHO DA SILVA ${ }^{4}$, \\ ELISA SERRA NEGRA VIEIRA ${ }^{5}$, MARISTELA PANOBIANCO $^{6}$
}

\begin{abstract}
The goal of the present study is to assess the physiological potential of Byrsonima crassifolia seeds and analyze the procedures of the germination and tetrazolium tests, as well as the conservation of such seeds by testing different combinations of packaging and environment. The experiment used pyrenes of the clone Açu, collected from mother plants in the germplasm collection of muruci plants of Embrapa Amazonia Oriental, in Belém, Brazil. Different temperatures were tested in the germination test $(25,30,35$ and $20-30{ }^{\circ} \mathrm{C}$ ). The best methodology and assessment dates were determined for the test, and the seedlings of the species were characterized. Viability was assessed with the tetrazolium test, with combinations of hydration methods (by immersion and between paper towels), staining periods ( 3 and $4 \mathrm{~h}$ ) and concentrations of tetrazolium solution $(0.5,0.7$ and $1.0 \%)$. Storage of muruci pyrenes was evaluated at three, six and twelve months, in polyethylene and Kraft paper bags, under dry chamber and refrigerator conditions. The study used a randomized block design with four replicates. The data underwent analysis of variance. In conclusion, the physiological potential of seeds of $B$. crassifolia can be assessed by the germination test conducted in sand, with alternating temperatures of $20-30{ }^{\circ} \mathrm{C}$, or with the use of the tetrazolium test (with staining for three hours in the tetrazolium solution at $1.0 \%$ ) as a rapid assessment of viability. Muruci pyrenes can be kept in polythene or paper Kraft bags for up to 12 months, in a dry chamber at $16{ }^{\circ} \mathrm{C}$ and with relative air humidity of 50 to $60 \%$.
\end{abstract}

Index terms: Pyrene, germination, tetrazolium test, storage.

\section{POTENCIAL FISIOLÓGICO E CONSERVAÇÃO DE SEMENTES DE MURUCI (Byrsonima crassifolia)}

\begin{abstract}
RESUMO - O objetivo deste trabalho foi avaliar o potencial fisiológico de sementes de Byrsonima crassifolia e estudar procedimentos dos testes de germinação e de tetrazólio, bem como sua conservação, testando combinações de embalagem e ambiente. Foram utilizados pirênios do clone Açu, coletados de plantas matrizes da Coleção de Germoplasma de murucizeiro da Embrapa Amazônia Oriental, em Belém - PA, Brasil. No estudo de germinação foram testadas diferentes temperaturas $\left(25,30,35\right.$ e $\left.20-30{ }^{\circ} \mathrm{C}\right)$, procurando-se definir a melhor metodologia e as datas de avaliação do teste, bem como a caracterização das plântulas. $\mathrm{Na}$ avaliação da viabilidade pelo teste de tetrazólio, testou-se combinações de formas de hidratação (por imersão e entre papel), períodos de coloração (3 e 4 h) e concentrações da solução de tetrazólio $(0,5 ; 0,7$ e $1,0 \%$ ). O armazenamento dos pirênios de muruci foi avaliado aos três, seis e 12 meses, em embalagens de polietileno e papel tipo Kraft, sob condições de câmara seca e refrigerador. O delineamento experimental foi inteiramente casualizado, com quatro repetições e os dados submetidos à análise de variância. Concluise que o potencial fisiológico das sementes de $B$. crassifolia pode ser avaliado pelo teste de germinação conduzido entre areia, com temperatura alternada de $20-30{ }^{\circ} \mathrm{C}$, ou com o uso do teste de tetrazólio (com coloração por três horas na solução de tetrazólio a 1,0\%) como avaliação rápida da viabilidade. Os pirênios de muruci podem ser conservados em embalagem de polietileno ou papel tipo Kraft por até 12 meses, em câmara com temperatura de $16^{\circ} \mathrm{C}$ e umidade relativa de 50 a $60 \%$.
\end{abstract}

Termos para indexação: Pirênio, germinação, teste de tetrazólio, armazenamento.

${ }^{1}$ (Paper 100-16). Received August 04, 2016. Accepted December 06, 2016.Part of the doctoral dissertation produced by the first author at the Graduate Program in Agronomy/Crop Production, Federal University of Paraná.

${ }^{2}$ Agronomist. PhD in Agronomy - Crop Production. E-mail: camilaribeirodesouza@gmail.com

${ }^{3}$ Agronomist. Researcher at Embrapa Amazônia Oriental. E-mail: walnice.nascimento@embrapa.br

${ }^{4}$ Agronomist. Professor at Instituto Federal do Paraná. E-mail: rosemeire.silva@ifpr.edu.br

${ }^{5}$ Agronomist. Researcher at Embrapa Florestas. E-mail: elisa.vieira@embrapa.br

${ }^{6}$ Agronomist. Professor at the Federal University of Paraná. E-mail: maristela@ufpr.br. 


\section{INTRODUCTION}

Muruci (Byrsonima crassifolia (L.) H.S.K.) is native forest species of the Malpighiaceae family, with center of origin and dispersion in the Amazon. It has wide geographic distribution in the Brazilian territory and spontaneous occurrence, with greater frequency and abundance in the North, Northeast and Midwest (CAVALCANTE, 2010, FLORA BRASIL, 2016). Although muruci is considered to have multiple use (marketing of fruit or timber production), the fruit itself is explored to a greater extent because of market value. The fruit of muruci is eaten fresh or processed, in the form of juice, ice cream, candy, among other food products. It has become an important food resource for low-income rural populations (CARVALHO et al., 2006).

The dispersion and propagation unit is the pyrene, popularly called stone, which is made up of the endocarp and the seeds. The seeds are not used as propagation units because it is difficult to remove them from the inside of the endocarp without impairing germination capacity, as mechanical damage occurs during extraction (CARVALHO; NASCIMENTO, 2008)

Studies with native species should involve the development of methods for production on a large scale, as well as knowledge of particular information: factors that influence propagation, appropriate processing of fruits and seeds, determination of optimal conditions for germination and storage of seeds (PEREIRA et al., 2010).

For muruci seeds, germination is slow and uneven, with seedling emergence at 20 days after sowing, and it may extend for periods longer than 200 days, because although the endocarp is permeable, it may impose mechanical resistance to the expansion of the embryo (CARVALHO et al., 2006). Therefore, previous studies were conducted to assess pre-germination treatments whose aim was to accelerate germination for production of seedlings of the species, e.g. those by Carvalho and Nascimento (2008 and 2013), which reported that each lot may have or not a variable amount of physically and/ or physiologically dormant seeds, with distinct responses.

In the instructions for analysis of seeds of forest species (BRASIL, 2013), there are some recommendations for the germination test in muruci seeds; for example, germination in sand at $25^{\circ} \mathrm{C}$ for 40 days. However, the methodology is based on the complementation of several works reported in the literature, hence it has not been validated yet; in addition, there is not enough information to run the test protocol, e.g. on characterization of seedlings and days of count. Thus, specific studies are required to define the best methodology, covering all the stages of the germination test, in order to support assessments in the laboratory and new production techniques, hence encouraging the use and marketing of seeds of this species.

The physiological potential of seeds represents the theoretical capacity or likelihood of success of the seeds to manifest their vital functions, whether under favorable environmental conditions or not (MARCOS-FILHO, 2015). Therefore, it is crucial to identify methods for rapid assessment of this potential, especially for species that have slow germination such as muruci. Among the procedures available, the tetrazolium test is quite an interesting option because it enables the rapid assessment of seed viability by means of a careful analysis. Also, it is not affected by conditions that can change the results of the germination test, e.g. the occurrence of dormancy and micro-organisms.

The principle of the tetrazolium test is based on the activity of dehydrogenase enzymes, which catalyze the respiratory reactions in mitochondria. The test relates seed viability with change in the color of living tissues, caused by an oxidation-reduction reaction with 2,3,5-triphenyl tetrazolium chloride (FRANÇA NETO, 1999). This change results in the formation of a red, stable, non-diffusible compound: formazan. This is indicative of respiratory activity in the mitochondria and allows a distinction between living tissues and those which remain unstained or show abnormal staining (MARCOS-FILHO, 2015).

When seeds are used, conservation methods have to be determined to minimize loss of quality during storage by using techniques to maintain conditions more suitable for the storage environment, i.e., air temperature and relative humidity have to be controlled in order to minimize metabolic activity, which is closely related to water content (MARCOSFILHO, 2015, MARTINI NETO).

For this reason, the aim of the present research was to assess the physiological potential of seeds of Byrsonima crassifolia (L.) H.B.K. by analyzing the use of the germination and tetrazolium tests, as well as the conservation of such seeds, by testing combinations of packaging and storage environment.

\section{MATERIAL AND METHODS}

The study was conducted over four years using pyrenes (endocarps + seeds) from fruits of the clone Açu of mother plants from the Active 
Germplasm Bank of muruci at Embrapa Amazonia Oriental, in Belém, Pará, Brazil (registered with the Ministry of the Environment under protocol no. 037/2010-SECEX/CGEN). This material was selected because it has excellent seed quality.

After collection, the pulp and the pyrenes were manually removed from the fruits. The pyrenes were subsequently dried on paper towel and placed in a desiccator containing silica gel, until water content in the pyrenes was reduced from $17-22 \%$ to $5.0-7.0 \%$. Before each test, water content of the pyrenes was determined with the oven method at $105 \pm 3{ }^{\circ} \mathrm{C}$ for 24 hours (BRASIL, 2009), with two replicates of $5 \mathrm{~g}$.

Initially, the pyrenes were homogenized manually (BRASIL, 2009) and divided into four subsamples, which originated the replicates During the experimental period, they were stored in Kraft paper bags in a controlled environment (temperature $16 \pm 2^{\circ} \mathrm{C}$ and $50-60 \%$ relative air humidity).

\section{Germination test}

The study of the germination test was performed at two stages, depending on the amount of pyrenes collected in each harvest. The experimental design was completely randomized. The data underwent analysis of variance and the means were compared by Tukey's test $(p \leq 0.01)$ for each harvest. Fruits collected in the 2011 harvest of were used. Eight subsamples of 25 pyrenes were planted in plastic boxes $(13.0 \times 18.5 \times 11.0 \mathrm{~cm})$ containing sand with mediumgrain size, previously sterilized in an autoclave ( $1 \mathrm{~atm}$ and $120{ }^{\circ} \mathrm{C}$ for 1 hour), with moisture at field capacity. The plastic boxes containing the pyrenes were placed in a Mangelsdorf germinator. Three constant temperatures were tested: 25,30 and $35^{\circ} \mathrm{C}$, without the supply of light.

The pyrenes from the 2012 harvest were used in a second study with the germination test in order to determine the optimum temperature for this test with muruci. At this stage, eight subsamples of 25 pyrenes were left to germinate as described previously, under constant temperatures of 25 and $30^{\circ} \mathrm{C}$ (as selected in the first study) and temperatures alternating between 20 and alternating $30^{\circ} \mathrm{C}$, without the supply of light.

The counts were performed every two days by observing the first normal seedling while characterizing normal and abnormal seedlings, until germination became constant, i.e., when there was no formation of seedlings any longer. At the end of the tests, germination percentage and germination speed index (MAGUIRE, 1962) were determined, and the first and the last counts were defined. To determine germination percentage, the pyrenes and the seedlings were removed in the counts, and only one normal seedling was counted. This is because pyrenes may contain two or three seeds which produce normal seedlings, which was often the case during the experiments.

Assessment of storage potential of pyrenes

To assess storage potential, pyrenes collected in the 2012 harvest were divided into four samples and placed in permeable (Kraft paper) bags and semipermeable (polyethylene) bags. They were kept in two environments: a) $5-10^{\circ} \mathrm{C}$ and $40-50 \%$ relative air humidity (refrigerator); b) $16 \pm 2{ }^{\circ} \mathrm{C}$ and $50-60 \%$ relative air humidity (dry chamber). The study used a split-plot design: the plots received the combinations between storage environments and packaging conditions while the subplots received the periods. Regression analysis was performed for evaluation of the physiological potential of pyrenes, with the best tendency beng fitted to the resulting curve.

Seed quality was assessed initially and at three, six and 12 months after storage by the following tests:

a) Germination test - conducted with eight replications of 25 pyrenes left to germinate as described in the study of the germination test for the 2011 harvest, with temperature of $25^{\circ} \mathrm{C}$, without the supply of light. The counts were performed every two days, based on the observation of the first normal seedling until 60 days after setup of the test. After that, germination percentage was calculated and the speed germination index was determined (MAGUIRE, 1962).

b) Water content - determined by the oven method at $105 \pm 3^{\circ} \mathrm{C}$ for 24 hours (BRASIL, 2009) with two replicates of $5 \mathrm{~g}$.

\section{Tetrazolium test}

The tetrazolium test was conducted with pyrenes collected in the 2013 harvest, in a completely randomized design (treatments $\mathrm{x}$ methods of assessment). The data underwent analysis of variance and the means were compared by Tukey's test ( $\mathrm{p} \leq$ $0.01)$. Initially, the feasibility of the pyrenes was determined by the germination test, in accordance with the best methodology found in the study of the 2012 harvest, i.e., in the alternating temperatures of $20-30^{\circ} \mathrm{C}$, without the supply of light.

The assessment of the tetrazolium test used four replicates of 40 pyrenes (Figure 1A) pre-conditioned by immersion in a beaker $(100$ $\mathrm{mL}$ capacity) containing $100 \mathrm{~mL}$ of tap water for 24 hours at $25^{\circ} \mathrm{C}$. After that, the endocarp was broken with a small bench vise (Figure 1B) for seed extraction (Figure 1C). After extraction, the seeds were analyzed visually and only those who had no damage resulting from breakage of the endocarp were 
maintained in subsequent steps.

The tetrazolium test was conducted with four replicates of 25 open embryos for each study treatment, and the following combinations were tested:

a) Hydration - the seeds were left to soak for 24 hours at $25^{\circ} \mathrm{C}$ by immersion in a beaker $(100$ $\mathrm{mL}$ capacity) with $50 \mathrm{~mL}$ of tap water and between a sheet of paper towel (Germilab) moistened with water equivalent to 2.5 times the weight of the dry paper;

b) Preparation of the seeds - the seed coat was removed by cutting the surface of seeds on the opposite side to the embryonic axis with the help of a stainless steel blade;

c) Staining - The embryos were placed in a dark environment for three to four hours, with concentrations of tetrazolium solution at $0.5,0.7$ and $1.0 \%$, at $40{ }^{\circ} \mathrm{C}$.

After staining, the embryos were removed from the chamber, washed in tap water and kept submerged in water under refrigeration $\left(5-10^{\circ} \mathrm{C}\right)$ until the time of assessment, which was performed no more than 24 hours after staining.

To assess seed viability, seed structures (Figure 1D and 1E) were observed with the aid of stereoscopic microscope. The seeds were classified as viable and non-viable depending on the color visible in the vital area (embryonic axis). They were assessed in two ways: (a) only externally; b) externally and internally after longitudinal bisection of the embryo with a stainless steel blade. The percentage of viable seeds was calculated for each treatment and method of assessment tested.

\section{RESULTS AND DISCUSSION}

\section{Germination test}

Table 1 shows the germination percentages and germination speed indexes (GSI) of muruci pyrenes from the 2011 harvest. The highest germination rates for the pyrenes from the 2011 harvest were found at 25 and $30^{\circ} \mathrm{C}$ (Table 1). For the pyrenes from the 2012 harvest, there was a higher rate of germination when temperatures ranged between $20^{\circ} \mathrm{C}$ and $30^{\circ} \mathrm{C}$, compared with constant temperatures; similarly, GSI was higher with temperature variation than when at $25^{\circ} \mathrm{C}$ (Table 1).

Based on the fact that the optimum temperature for germination is the result of the physiological adjustment of seeds to the environmental conditions of the sites of occurrence or cultivation of the species, there may be a direct relationship between such temperature and the biome where the seeds were produced (BRANCALION et al., 2010). In the case of muruci plants, the center of origin of the species is located in the Amazon Biome (CAVALCANTE, 2010), with hot and humid climate and temperatures around $25{ }^{\circ} \mathrm{C}$ (INMET, 2016). This explains the best results found in the germination test with temperatures of 25 and $30^{\circ} \mathrm{C}$.

In previous studies with muruci pyrenes, germination was successfully carried out under natural environment conditions in the city of Belém, PA (CARVALHO; NASCIMENTO, 2008 and 2013). These conditions are similar to the optimum temperature found in the present study, because the temperature is not constant in natural environments, with more prominent variations between the hours of the day and night. There is, therefore, a direct relationship between optimum temperature for germination $\left(20-30{ }^{\circ} \mathrm{C}\right)$ and the biome of origin of the seeds.

Figure 2 shows the percentage of normal seedlings per day of assessment over the total number of germinated seeds of muruci, at alternating temperatures. It was found that $65 \%$ of normal seedlings germinated until 24 days after the setup of the test. There was no formation of seedlings as of the 58th day, i.e., for muruci, the first and the last counts of the germination test should be carried out at 24 and 57 days after sowing.

The literature reports that the emergence of muruci seedlings can extend for periods longer than 200 days after sowing (CARVALHO et al., 2006); however, in their study, the muruci seeds were sown immediately after processing, i.e., with water content around $30 \%$. In the present study, it was found that the reduction in water content in the muruci seeds decreases seed dormancy. Thus, such reduction can be used to accelerate and standardize germination, since seedling development occurred up to 90 days at the latest at all study temperatures (in the two harvests). It should be noted that this period ranged depending on temperature. The shortest time between sowing and the non-formation of seedlings occurred at $20-30{ }^{\circ} \mathrm{C}$. According to Borghetti and Ferreira (2004), synchronism in seed germination is lower under extreme temperatures and tends to be greater when incubation temperature is more similar to the optimal range of germination.

Figure 3A shows the development of the muruci seedlings. The taproot is the first part of the seedlings which sprouts. Root growth is followed by hypocotyl growth, emergence of lateral roots and emergence of cotyledons; then, the seedling is fully formed. The seedlings of muruci are classified as 
epigeal, i.e., the cotyledons are pulled through the soil surface (CARVALHO et al., 1998).

Figures $3 \mathrm{~A}$ and $3 \mathrm{~B}$ show the normal and intact seedlings, whose essential structures are welldeveloped, complete, proportionate and healthy (Brasil, 2009), i.e., long and thin taproot with secondary roots, which taper toward the bottom; straight hypocotyl and two green cotyledons in opposite position. In the abnormal seedlings found in the study of the germination test, the taproot was twisted (Figures 3C and 3D), and the cotyledons had retained seed coat (Figure 3E), or were damaged as a result of primary infection (Figures 3C, 3D, 3F and $3 \mathrm{G})$ or were detached from the seedling ( $3 \mathrm{~F}$ and $3 \mathrm{G})$.

\section{Storage}

Storage was assessed with pyrenes collected in the 2012 harvest. There was variation in germination over the 12 months' assessment (Figure 4A). Storage in the dry chamber $\left(16 \pm 2{ }^{\circ} \mathrm{C}\right.$ and $50-60 \%$ relative air humidity) was particularly relevant, as it kept germination percentage statistically constant during the entire period, with 71 and $62 \%$ in the polyethylene and paper bags, respectively. However, there was $76 \%$ germination in the last evaluation at 12 months' storage, with paper bag in the refrigerator, i.e., there was a significant increase in germination percentage compared with all other periods.

The variation in germination percentages along the storage period can be explained by the presence of dormancy in muruci seeds (CARVALHO; NASCIMENTO, 2013). According to Marcos-Filho (2015), intensity of seed dormancy, regardless of its cause, is inversely proportional to seed age, i.e., it is more pronounced in freshly harvested seeds and decreases over time when stored properly.

Probably, there are four groups of pyrenes as far as dormancy is concerned: pyrenes in which the endocarp does no prevent germination and the seeds are not physiologically dormant; pyrenes in which the endocarp prevents the growth of the embryo and the seeds are not dormant; pyrenes in which the endocarp does not impose serious restrictions to germination, but the seeds are physiologically dormant and pyrenes in which the endocarp is quite sturdy, hindering the growth of the embryo, and the seeds are physiologically dormant (CARVALHO; NASCIMENTO, 2008).

In the literature, there are studies evaluating methods for overcoming physical and physiological dormancy of pyrenes of the genus Byrsonima, not only for the species $B$. crassifolia (CARVALHO; NASCIMENTO, 2008 and 2013) but also for $B$. cydoniifolia (MURAKAMI et al., 2011) and $B$. verbascifolia (ALBERTO et al., 2011). However, in seed lots used in all these studies, germination percentage in the control (pyrenes not submitted to treatment for overcoming dormancy) was not higher than $20 \%$.

This did not occur in the present study: even though pre-germination treatments were not used, germination values were around $60 \%$. The reason lies in the fact that the seeds were dried after the pyrenes were extracted, and the reduction of water content from $17.0-22.0 \%$ (when newly harvested) to $7.0-9.0 \%$ has an influence on overcoming dormancy, i.e., it reduces the limitation to the development of the embryo in the endocarp. It should be noted that the pre-drying is one of the methods for overcoming dormancy which is recommended for various species by the Rules for Seed Testing (BRASIL, 2009). Such positive effect on seed dormancy was also found for muruci.

Therefore, it can be inferred that in the pyrenes used in the present study, the endocarp offered no serious restrictions on germination, because it allowed the entry of water. However, some seeds were physiologically dormant, hence germination percentages varied along the storage period and increased at 12 months when the seeds were stored under refrigeration and in paper bags.

These variations in germination percentage can be explained by the strategy of survival of the species, which has genetic diversity since it is not genetically improved. Within a single sample, some seeds are ready to germinate: while some may lose viability along the storage period, for other seeds dormancy is overcome after storage, depending on the condition applied.

Germination speed index (vigor) showed the same behavior of germination along storage, i.e., the initial values remained constant when the seeds were kept in the chamber but increased when they were kept in the refrigerator for 12 months (Figure 4B). A comparison for type of packaging used for storage of pyrenes, namely, permeable (Kraft paper) and semipermeable (Polyethylene), showed no marked differences in the values of germination and vigor within the same environment (Figure 4). Thus, the two types of packages can be used, depending on on-site availability.

Water content remained constant and similar in all study conditions during the storage period, ranging from 8.8 to $9.8 \%$. The metabolic activity of the seeds within the storage environment has not suffered any major moisture-induced changes, thus reducing deterioration. Moreover, changes in physiological quality were due to factors intrinsic to the species, i.e., the presence or absence of dormancy. 
According to Marcos-Filho (2015), seed longevity is variable depending on genotype, but the period of preservation of physiological potential depends, to a large extent, on water content and the conditions of the storage environment, i.e., it is the characteristic most closely associated with deterioration.

Therefore, it should be noted that the storage of muruci pyrenes in the chamber $\left(16 \pm 2{ }^{\circ} \mathrm{C}\right.$ and $50-60 \%$ relative air humidity) with polythene or paper kraft is the best option for conservation, as it preserves their germination potential in the short (up to six months) and medium term (12 months). However, storage in the refrigerator should not be discarded as an option because the equipment is widely available; moreover, there was an increase in germination and vigor over 12 months in comparison with time zero, i.e., if nurserymen do not use pyrenes in the short term, the latter can be kept under refrigeration $\left(5-10^{\circ} \mathrm{C}\right)$ in permeable or semipermeable packaging without loss of quality.

\section{Tetrazolium test}

Table 2 shows the data on seed viability of muruci (2013 harvest), assessed in the germination and tetrazolium tests. There was no interaction between method of assessment and the study combinations. The assessment of the inner and outer parts, in order to check the extent of damage, was made through longitudinal bisection of the embryos. It was the best way to interpret the tests, since it provided clear results. Moreover, it showed that the values of viability percentage were similar to those of germination.

Among the treatments with hydration of seeds between paper towels, staining by immersion in the tetrazolium solution at $0.7 \%$ for three hours (Table 2) was the most effective, as it showed a similar result as in the germination test. The results showed the possibility of using the solution with a lower concentration $(0.7 \%)$ than the one commonly recommended for species with an indication of the tetrazolium test by the International Seed Testing Association (ISTA, 2003). However, during the implementation of the test, it is difficult to visualize essential structures and determine seed feasibility in such concentration, because the tissues are weakly stained.

When the seeds were hydrated by soaking in water, the methodology in which viability percent was similar to that of the germination test was staining for three hours in a solution at 1.0\% (Table 2 ). At this concentration, it was easy to visualize the essential parts of the seed structure. In addition, this protocol of conduction of the tetrazolium test enabled the evaluation of the viability of muruci seeds in less than three days (approximately 53 hours). This is particularly important because the period for final count of the germination test is 57 days; also, the seeds may be dormant.

The tetrazolium test is not affected by some factors that may change the results of the germination test, e.g., presence of fungi. Moreover, it has some advantages: it focuses on the physical and physiological conditions of the embryo of each individual seed; it enables rapid assessment of viability; it can identify the cause of loss of seed viability; it requires simple equipment; it is a low-cost test (FRANÇA NETO, 1999).

Figure 5 shows the structures of tissues of the embryo of muruci seeds after staining with tetrazolium solution at $1.0 \%$. Both viable and nonviable embryos are shown. In muruci seeds, vital areas considered for evaluation were the embryonic axis and the region of its connection with the cotyledons (Figures 5D and 5E). Thus, the embryos were classified into two groups:

a) Viable embryos - when they had firm tissue with a red color clear throughout the embryo (Figures $5 \mathrm{~A}$ and $5 \mathrm{I}$ ), or when they were damaged outside of vital areas (Figures 5B and 5C) which do not prevent germination or the establishment of normal seedlings;

b) Non-viable embryos - when they had soft and/or white tissue, caused by a reduction in tetrazolium salts in the region of the embryonic axis and in the region of connection with the cotyledons or in the whole embryo (Figures 5D, 5E, 5F, 5G, 5H, $5 \mathrm{~K}$ and $5 \mathrm{~L}$ ); bright red tissue in the vital areas or in the whole embryo (Figures 5E, 5J and 5L), indicating severely deteriorated tissues, with poor respiratory activity.

The findings showed that the tetrazolium test is a promising method for rapid determination of seed viability of muruci with pre-conditioning by immersion of pyrenes in water for 24 hours at $25^{\circ} \mathrm{C}$, seed extraction from the endocarp, hydration of seeds by soaking in water $\left(24\right.$ hours at $\left.25^{\circ} \mathrm{C}\right)$, seed coat removal and staining of embryos $\left(3\right.$ hours at $\left.40^{\circ} \mathrm{C}\right)$ in a tetrazolium solution at $1.0 \%$. 
TABLE 1 - Germination and germination speed index (GSI) of pyrenes of Byrsonima crassifolia, under different temperatures, at two consecutive harvests.

\begin{tabular}{ccc}
\hline & 2011 & \\
\hline Temperature & Germination(\%) & GSI \\
\hline $25^{\circ} \mathrm{C}$ & $72 \mathrm{a}$ & $0.612 \mathrm{a}$ \\
$30^{\circ} \mathrm{C}$ & $56 \mathrm{a}$ & $0.591 \mathrm{a}$ \\
$35^{\circ} \mathrm{C}$ & $22 \mathrm{~b}$ & $0.140 \mathrm{~b}$ \\
\hline C.V. $(\%)$ & 11.62 & 11.93 \\
\hline & 2012 & $G S I$ \\
\hline Temperature & Germination (\%) & $0.433 \mathrm{~b}$ \\
\hline $25^{\circ} \mathrm{C}$ & $53 \mathrm{~b}$ & $0.679 \mathrm{ab}$ \\
$30^{\circ} \mathrm{C}$ & $61 \mathrm{~b}$ & $0.850 \mathrm{a}$ \\
\hline $20-30{ }^{\circ} \mathrm{C}$ & $84 \mathrm{a}$ & 19.56 \\
\hline C.V. $(\%)$ & 16.51 &
\end{tabular}

*Means followed by the same letter in the column do not differ statistically by Tukey's test $(\mathrm{p} \leq 0.01)$ in each harvest

TABLE 2 - Percentage of viable seeds of Byrsonima crassifolia (2013 harvest) evaluated by the germination and tetrazolium tests (TZ).

\begin{tabular}{|c|c|c|c|}
\hline \multirow[b]{2}{*}{ Treatments } & \multicolumn{3}{|c|}{ Viable } \\
\hline & Evaluation externally & $\begin{array}{c}\text { Evaluation externally }+ \\
\text { internally }\end{array}$ & Means \\
\hline & \multicolumn{3}{|c|}{ 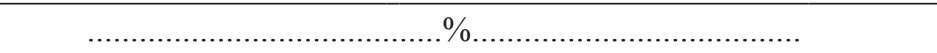 } \\
\hline Germination & 61 & 61 & $61 \mathrm{~b}$ \\
\hline \multicolumn{4}{|c|}{ Hydration between paper } \\
\hline $\mathrm{TZ} 1.0 \% 3 \mathrm{~h}$ & 68 & 65 & $67 \mathrm{ab}$ \\
\hline TZ $1.0 \% 4 \mathrm{~h}$ & 81 & 71 & $76 \mathrm{a}$ \\
\hline TZ $0.7 \% 3 \mathrm{~h}$ & 64 & 58 & $61 \mathrm{~b}$ \\
\hline $\mathrm{TZ} 0.7 \% 4 \mathrm{~h}$ & 65 & 61 & $63 \mathrm{ab}$ \\
\hline TZ $0.5 \% 3 \mathrm{~h}$ & 73 & 74 & $69 \mathrm{ab}$ \\
\hline $\mathrm{TZ} 0.5 \% 4 \mathrm{~h}$ & 67 & 62 & $65 \mathrm{ab}$ \\
\hline \multicolumn{4}{|c|}{ Hydration by immersion } \\
\hline $\mathrm{TZ} 1.0 \% 3 \mathrm{~h}$ & 63 & 59 & $61 \mathrm{~b}$ \\
\hline $\mathrm{TZ} 1.0 \% 4 \mathrm{~h}$ & 76 & 65 & $71 \mathrm{ab}$ \\
\hline $\mathrm{TZ} 0.7 \% 3 \mathrm{~h}$ & 69 & 55 & $62 \mathrm{ab}$ \\
\hline TZ $0.7 \% 4 h$ & 64 & 59 & $62 \mathrm{ab}$ \\
\hline TZ $0.5 \% 3 \mathrm{~h}$ & 72 & 52 & $62 \mathrm{ab}$ \\
\hline TZ $0.5 \% 4 \mathrm{~h}$ & 70 & 60 & $65 \mathrm{ab}$ \\
\hline Means & $69 \mathrm{~A}$ & $61 \mathrm{~B}$ & \\
\hline C.V. $(\%)$ & & & \\
\hline
\end{tabular}

*Means followed by the same low ${ }^{\circ}$ ercase letter in the column and uppercase letter in the line do not differ by Tukey's test ( $\left.\mathrm{p} \leq 0.01\right)$. 


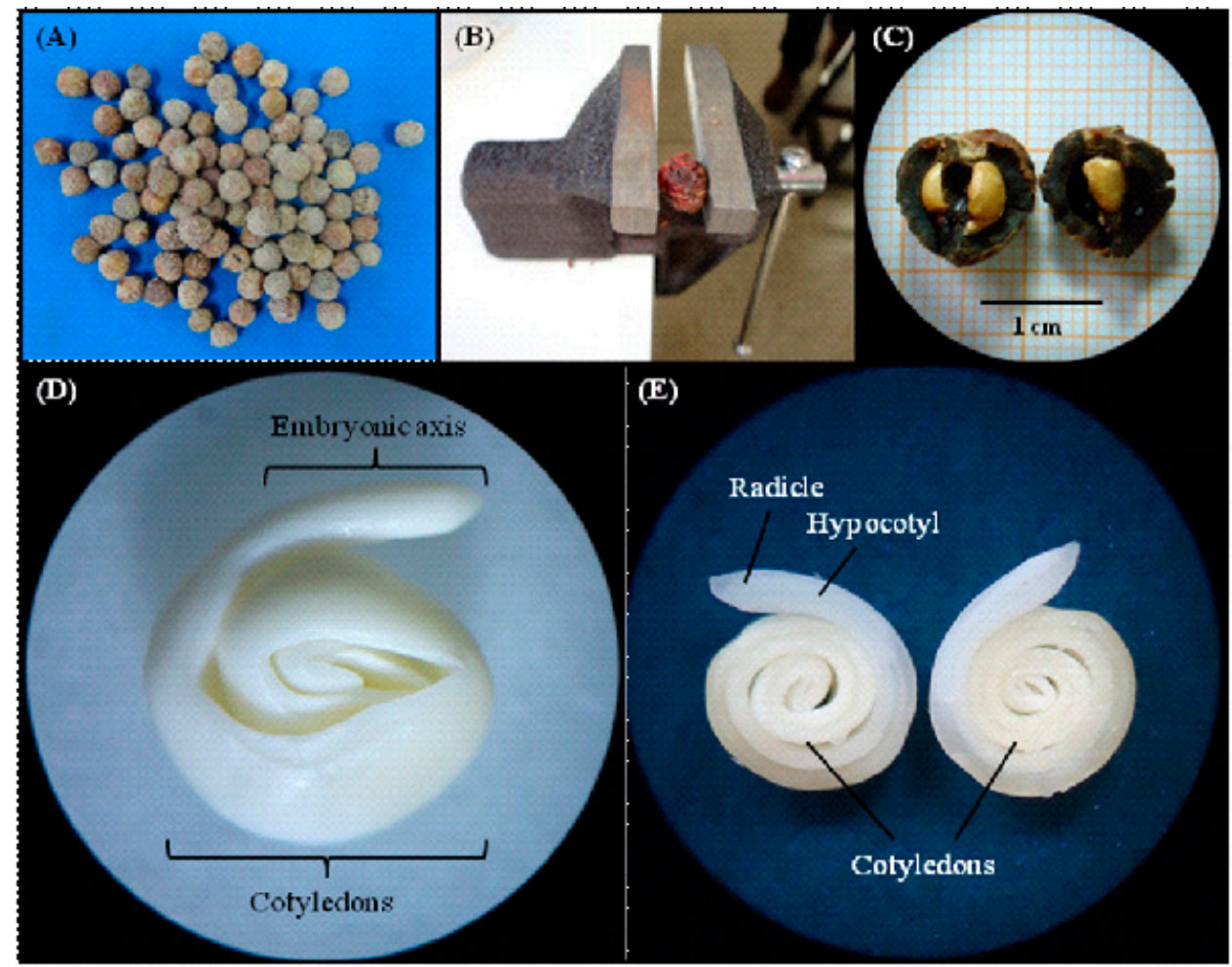

FIGURE 1 - Characteristics of the propagation of Byrsonima crassifolia: (A) intact pyrenes; (b) pyrene broken with help of a small bench vise; (C) open pyrenes (endocarps + seed); (D) embryo; (e) internal morphology of the embryo.

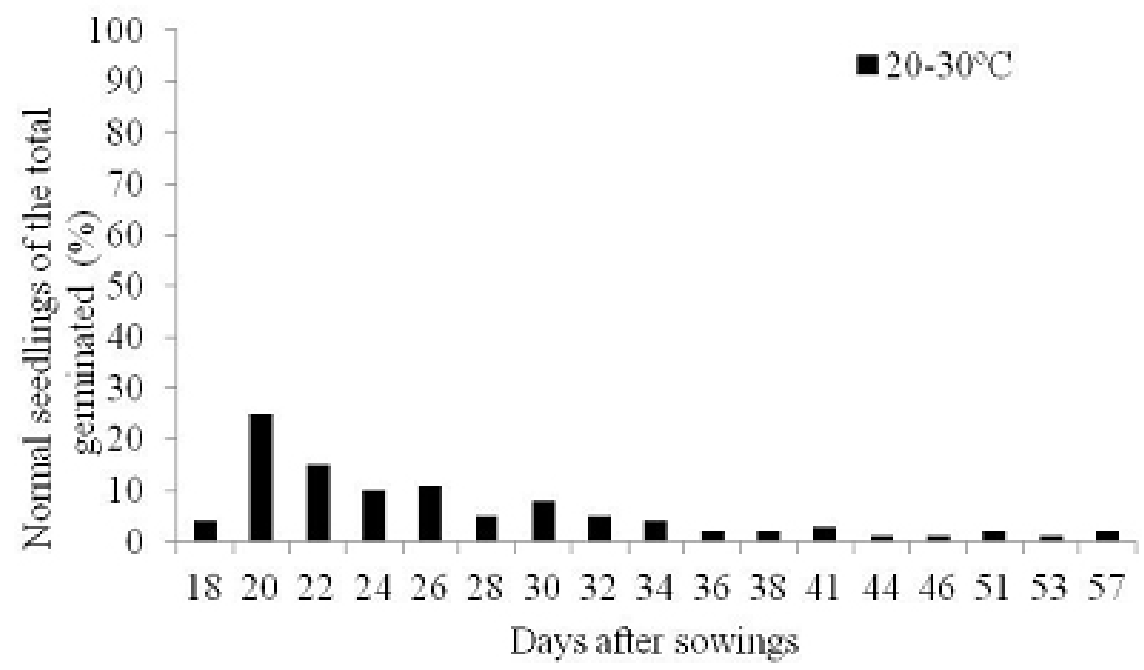

FIGURE 2 - Percentage of normal seedlings per day of assessment on the total number of germinated pyrenes of Byrsonima crassifolia, $20-30^{\circ} \mathrm{C}$, without incidence of light. 


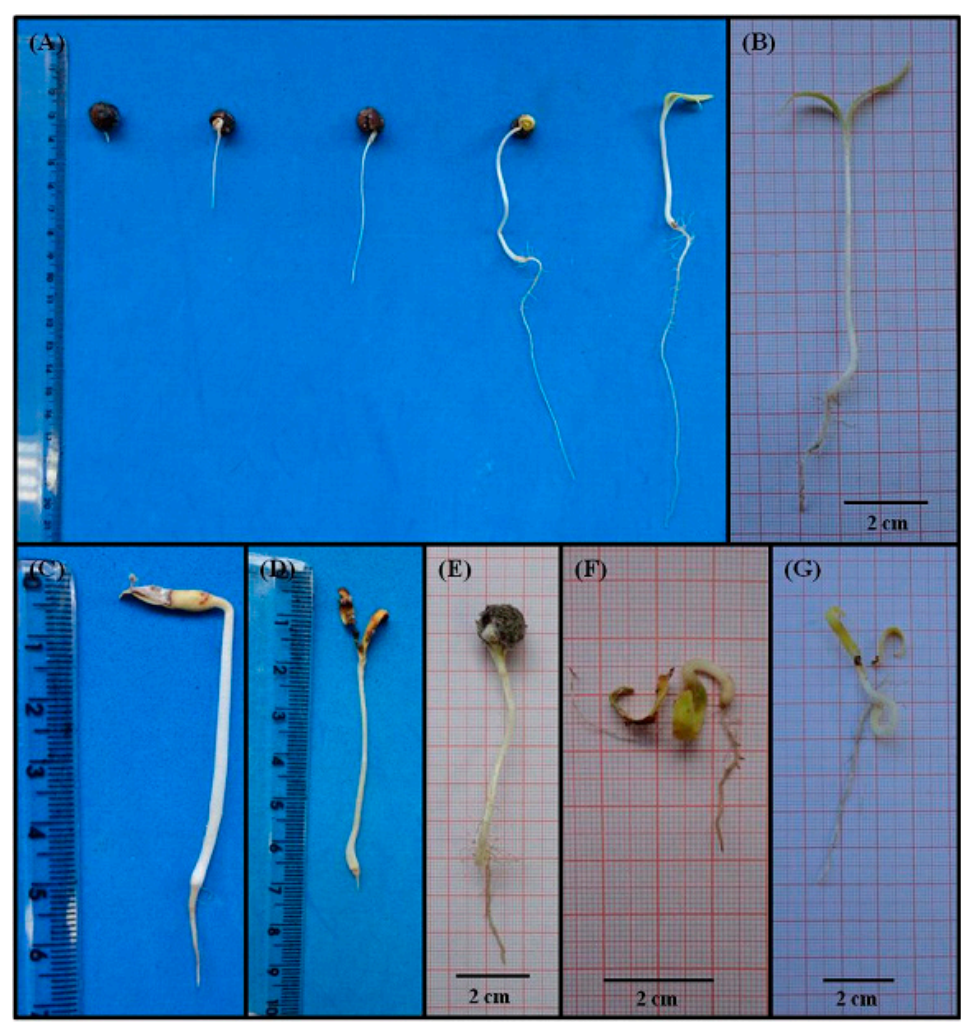

FIGURE 3 - Seedlings of Byrsonima crassifolia: development, normal and healthy seedlings (A, B) and abnormal and damaged seedlings (C, D, E, F and G).

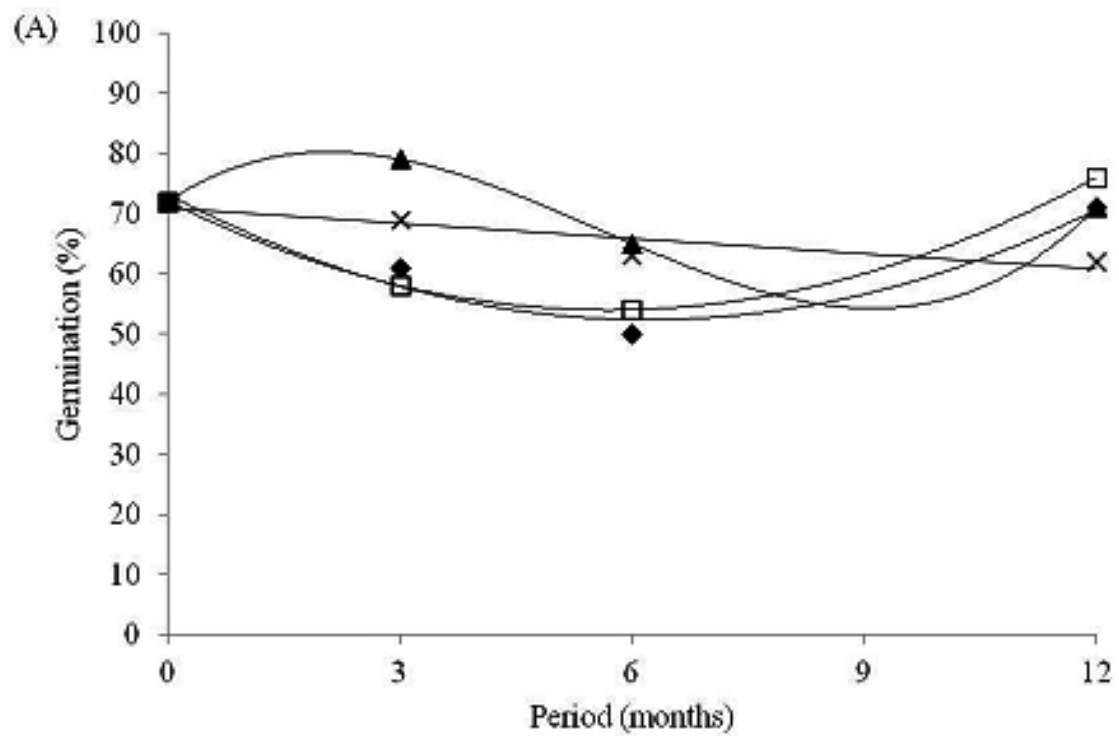

- Refrigerator - polyetylene: $y=73.18-6.75 \mathrm{x}+0.55 \mathrm{x} 2 \mathrm{R} 2=0.95^{* *}$

$\square$ Refrigerator - paper: $y=73.25-7.94 x+0.68 \times 2 \mathrm{R} 2=0.96^{* *}$

$\Delta$ Diy chamber - polyetylene: $\mathrm{y}=72.00+8.22 \mathrm{x}-2.44 \times 2+0.16 \times 3 \mathrm{R} 2=0.99^{* *}$

$\times$ Dry chamber - paper. $y=71.07-0.85 \times R 2=0.93^{*}$ 


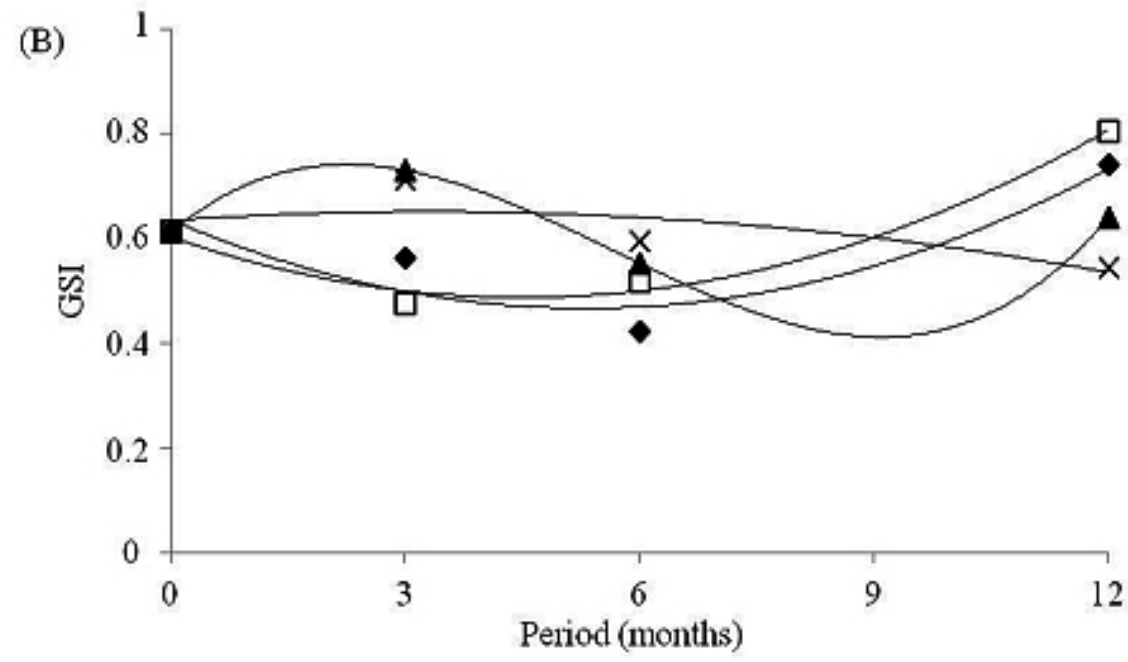

- Refrigerador - polietileno: $y=0.64-0.06 x+0.006 x 2 \mathrm{R} 2=0.87^{\text {*** }}$

$\square$ Refrigerador - papel: $y=0.60-0.05 x+0.006 \times 2$ R2 $=0.98^{* *}$

$\Delta$ Câmara - polietileno: $\mathrm{y}=0.61+0.13 \mathrm{x}-0.03 \times 2+0.002 \times 3 \mathrm{R} 2=0.99^{* *}$

$\times$ Câmara - papel: $\mathrm{y}=0.63+0.01 \mathrm{x}-0.002 \times 2 \mathrm{R} 2=0.58^{*}$

FIGURE 4 - Germination (A) and germination speed index - GSI (B) of pyrenes of Byrsonima crassifolia (2012 harvest) stored for 12 months in different environments and packages. $(*)$ and $(* *)$ significance at $\mathrm{p} \leq 0.05$ and $\mathrm{p} \leq 0.01$, respectively by the F-test.

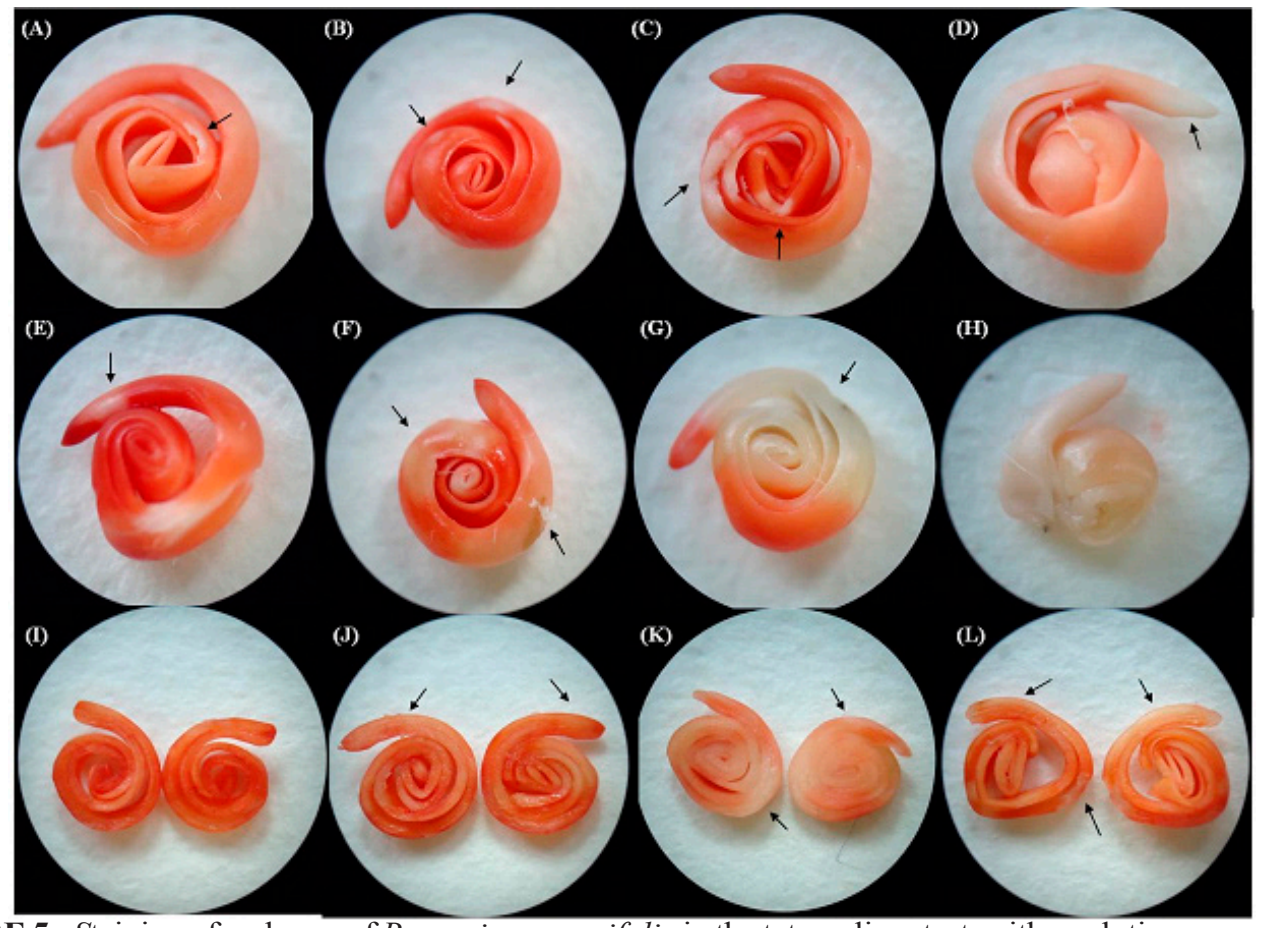

FIGURE 5 - Staining of embryos of Byrsonima crassifolia in the tetrazolium test, with a solution concentration of $1.0 \%$ for three hours: group of viable seeds (A, B, C, (I) and group of unviable seeds (D, E, F, G, H, J, K, L). 


\section{CONCLUSIONS}

The physiological potential of seeds of Byrsonima crassifolia can be assessed through the germination test conducted in sand, with temperatures ranging between 20 and $30^{\circ} \mathrm{C}$, or with the use of the tetrazolium test, with staining for three hours in a tetrazolium solution at $1.0 \%$, as a rapid assessment of viability.

Seed dormancy can be overcome with the aid of two procedures: drying muruci pyrenes and reducing water content to 5.0 to $7.0 \%$. They are suitable procedures to accelerate and standardize germination.

Muruci pyrenes can be conserved with use of polythene or Kraft paper for up to 12 months in a chamber with temperature of $16 \pm 2^{\circ} \mathrm{C}$ and relative air humidity of $50-60 \%$, without affecting germination potential.

\section{ACKNOWLEDGEMENTS}

We are thankful to the National Council for Scientific and Technological Development for the research fund granted.

\section{REFERENCES}

ALBERTO, P. S.; SILVA, F. G.; CABRAL, J. S. R.; SALES, J. F.; PERIERA, F. D. Methods to overcome of the dormancy in murici (Byrsonima verbascifolia Rich) seeds. Semina: Ciências Agrárias, Londrina, v.32, n.3, p.1015-1020, 2011.

BORGHETTI, F.; FERREIRA, A.G. Interpretação de resultados de germinação. In: FERREIRA, A.G.; BORGUET, F. (Ed.). Germinação: do básico ao aplicado. Porto Alegre: ARTMED, 2004. cap.13, p.209-222.

BRANCALION, P.H.S.; NOVEMBRE, A.D.L.C.; RODRIGUES, R.R. Temperatura ótima de germinação de espécies arbóreas brasileiras. Revista Brasileira de Sementes, Londrina, v.32, n.4, p.1521, 2010.

BRASIL. Ministério da Agricultura, Pecuária e Abastecimento. Instruções para análise de sementes de espécies florestais. Brasília, DF: MAPA/SDA, 2013. 97p.
BRASIL. Ministério da Agricultura, Pecuária e Abastecimento. Regras para análise de sementes. Brasília, DF: MAPA/ACS, 2009. 395p.

CARVALHO, J. E. U.; NASCIMENTO, W. M. O.; MÜLLER, C. H. Características físicas e de germinação de sementes de espécies frutíferas nativas da Amazônia. Belém: Embrapa Amazônia Oriental, 2006. 27p. (Documentos, 261).

CARVALHO, J. E. U.; NASCIMENTO, W. M. O.; MÜLlER, C. H. Propagação do Murucizeiro. Belém: Embrapa Amazônia Oriental, 1998. 18p. (Boletim de Pesquisa, 203).

CARVALHO, J.E.U.; NASCIMENTO, W.M.O. Caracterização biométrica e respostas fisiológicas de diásporos de murucizeiro a tratamentos para superação da dormência. Revista Brasileira de Fruticultura, Jaboticabal, v.35, n.3, p.704-712, 2013.

CARVALHO, J.E.U.; NASCIMENTO, W.M.O. Classificação dos pirênios e métodos para acelerar a germinação de sementes de muruci do clone Açu. Revista Brasileira de Fruticultura, Jaboticabal, v.30, n.3, p.775-781, 2008.

CAVALCANTE, P.B. Frutas comestíveis na Amazônia. 7.ed. Belém: Museu Paraense Emílio Goeldi, 2010. 282p. (Coleção Adolpho Ducke).

FLORA BRASIL. Angiospermas in flora do Brasil 2020 em construção. Rio de Janeiro: Jardim Botânico, 2016. Disponível em: $<$ http://floradobrasil. jbrj.gov.br/reflora/floradobrasil/FB128482>. Acesso em: 15 abr. 2016.

FRANÇA NETO, J.B. Teste de tetrazólio para determinação do vigor de sementes. In: KRZYZANOWSKI, F.C.; VIEIRA, R.D.; FRANÇA NETO, J.B. (Ed.). Vigor de sementes: conceitos e testes. Londrina: ABRATES, 1999. cap.8, p.1-7.

INMET - Instituto Nacional de Meteorologia. Climatologia - dados históricos. Brasília, DF, 2016. Disponível em: $\leq$ http://www.inmet.gov.br/ $>$. Acesso em: 15 abr. 2016.

ISTA - International Seed Testing Association. In: ISTA working sheets on tetrazolium testing. Bassersdorf: ISTA, 2003. v.1, 171p. 
MAGUIRE, J.D. Speed of germination - aid in selection and evolution for seedling emergence and vigor. Crop Science, Madison, v.2, n.1, p.176-177, 1962.

MARCOS-FILHO, J. Fisiologia de sementes de plantas cultivadas. 2.ed. Londrina: ABRATES, 2015. $660 \mathrm{p}$.

MARTINI NETO, N.; BARBEDO, C.J. Viability of Brazil wood seeds (Caesalpinia echinata Lam.) stored at room temperature in controlled atmospheres. Journal of Seed Science, Londrina, v.37, n.2, p.93-101, 2015.
MURAKAMI, D.M; BIZÃO, N.; VIEIRA, R.D. Quebra de dormência de semente de murici. Revista Brasileira de Fruticultura, Jaboticabal, v.33, n.4, p.1257-1265, 2011.

PEREIRA, C.; CUQUEL, F.L.; PANOBIANCO, M. Germinação e armazenamento de sementes de Nidularium innocentii (Lem.). Revista Brasileira de Sementes, Londrina, v.32, n.2, p.36-41, 2010. 